\title{
Selecting Lemon Protoplasts for Insensitivity to Phoma tracheiphila Toxin and Regenerating Tolerant Plants
}

\author{
Z.N. Deng1, A. Gentile, F. Domina, E. Nicolosi, and E. Tribulato \\ Istituto di Coltivazioni arboree, University of Catania, 95123 Catania, Italy \\ Additional index words. citrus breeding, Citrus limon, in vitro selection, protoclone, mal secco, chitinase
}

\begin{abstract}
Protoplasts isolated from an embryogenic callus line of 'Femminello siracusano' lemon [Citrus limon (L.) Burm. $f$. ] were incubated with $0.5 \mu$ toxin of Phoma tracheiphila (Petri) Kanc. et Ghik., the pathogen of the mal secco disease, which seriously damages most commercial lemon cultivars. Two toxin-tolerant cell lines were obtained, and plants were regenerated from each line. The selected protoclones were tested for their tolerance by exposing callus and protoplasts to the toxin and detecting chitinase (a pathogenesis-related protein) among the intra- and extracellular proteins extracted from leaves of regenerated plants and suspension culture, respectively. The tolerance of the protoclones in these tests was equivalent to the tolerant lemon cultivar Monachello, and they were substantially more tolerant than their mother cultivar Femminello siracusano.
\end{abstract}

The development of disease-resistant plants is a high priority for citrus-breeding programs. This objective is particularly important for lemon (Citrus limon), because most commercial cultivars are seriously damaged by a tracheomycotic disease, mal secco, which is caused by Phoma tracheiphila. The few tolerant cultivars, such as 'Monachello', are of poor bioagronomic characteristics. This disease can not be controlled successfully by chemicals or agricultural practices. Traditional crosses and clonal selection have not revealed any lemon hybrid or clone that combine mal secco tolerance with good fruit quality (Russo and Tribulato, 1986).

An alternative approach to conventional breeding is based on plant tissue and cell cultures. By in vitro selection, using toxic metabolites produced by pathogens as selective agents, diseaseresistant somaclones have been obtained in various host-pathogen systems (Daub, 1986; Hammerschlag, 1992). A toxin-tolerant somaclone was obtained by the selection of 'Femminello Continella' lemon embryogenic callus (Gentile et al., 1992b); the putative tolerant plants, regenerated from this cell line, have not shown any mal secco symptoms for 3 years in an area where $P$. tracheiphila is endemic. Somatic hybridization has also been used to transfer tolerant genes into susceptible lemons (Deng et al., 1995; Tusa et al., 1990). The different responses of citrus callus and protoplasts to the toxin provide a sensitive bioassay to evaluate the tolerance or the susceptibility of the tested genotypes to mal secco disease (Gentile et al., 1992a).

In studies on host-pathogen relationships, synthesis and accumulation of one or more specific proteins have been observed in many plants under biotic and abiotic stresses. These metabolites, termed pathogenesis-related (PR) proteins, seem to play an important role in the induction of resistance to disease by attacking the cell walls of the pathogens (Linthorst, 1991). In citrus, it was observed that the release of chitinase (a PR protein) in extra- and intracellular proteins of different genotypes was strongly correlated with the known field behavior toward the mal secco disease

Received for publication 14 Mar. 1995. Accepted for publication 12 June 1995. The cost of publishing this paper was defrayed in part by the payment of page charges. Under postal regulations, this paper therefore must be hereby marked advertisement solely to indicate this fact.

'Visiting scholar from Hunan Horticultural Research Institute, Changsha 410125, P.R. China.
(Gentile et al., 1994). In an experiment with three Citrus species, it was also found that ethylene (an inducer of PR proteins) increased the content and activities of glucanase and chitinase in the extra- and intracellular leaf extracts (Dahan and Sagee, 1992).

The objectives of this research were to select lemon protoplasts for insensitivity to $P$. tracheiphila toxin, to regenerate diseasetolerant plants from a susceptible Italian cultivar with excellent bioagronomic performance and high commercial value, and to characterize toxin-tolerant calli and regenerated plants for chitinase production and activity.

\section{Materials and Methods}

\section{Selection procedure}

Protoplast isolation. Embryogenic nucellar callus of 'Femminello siracusano' lemon was obtained from undeveloped ovule culture and maintained as described by Gentile and Deng (1992). Callus protoplasts were isolated according to Grosser and Gmitter (1990). Briefly, about $500 \mathrm{mg}$ of friable callus (3 weeks old) was mechanically macerated into $8 \mathrm{ml}$ of $\mathrm{BH} 3$ medium in 100 $\times 15$-mm petri dishes, after drop-by-drop addition of $2 \mathrm{ml}$ enzyme solution [0.7 M mannitol, $12.0 \mathrm{~mm} \mathrm{CaCl}, 6.0 \mathrm{~mm} \mathrm{MES}, 1.4 \mathrm{~mm}$ $\mathrm{NaH}_{2} \mathrm{PO}_{4}, 1 \%$ cellulase (Onozuka R- 10, Yakult Honsha Co. Ltd., Tokyo), $1 \%$ macerozyme (Onozuka R- 10 ), $0.2 \%$ pectinase (Sigma, St. Louis), pH 5.6, filter-sterilized]. The petri dishes, sealed with Nescofilm (Karlan Chemical, Torrance, Calif.), were placed for 1 $\mathrm{h}$ on a rotatory shaker at $50 \mathrm{rpm}$ and then incubated in dark at $27 \mathrm{C}$ for about $14 \mathrm{~h}$. The resulting protoplast preparation was passed through 55- and 30- $\mu \mathrm{m}$ nylon mesh filters to remove undigested cell clumps and debris. The filtrate was centrifuged for $5 \mathrm{~min}$ at $800 \times \mathrm{g}$ to remove the enzyme solution, and the protoplasts were washed two times with $\mathrm{BH} 3$ by centrifugation. The concentration was adjusted to $5 \times 10^{5}$ cells $/ \mathrm{ml}$.

Production of partially purified toxin. The toxin was partially purified according to the procedure described by Nachmias et al. (1977) from a liquid culture of $P$. tracheiphila ' 80 ' (+) isolate, which produces a high amount of protein in vitro (Pennisi et al., 1988). The protein content was determined according to Bradford (1976).

Toxin treatment. In a centrifuge tube, $0.6 \mathrm{ml}$ of $4 \mu \mathrm{M}$ toxin was mixed with $4.2 \mathrm{ml}$ of protoplast suspension to reach a final toxin concentration of $0.5 \mu \mathrm{M}$. After $1 \mathrm{~h}$ incubation in dark at $27 \mathrm{C}$, the 
treated-protoplasts were washed twice with $\mathrm{BH} 3$ medium by centrifugation at $800 \times g$ for $5 \mathrm{~min}$ each. The protoplast suspension was mixed with the same volume of MT medium (Murashige and Tucker, 1969) melted to 50C containing $50 \mathrm{~g} \cdot \mathrm{liter}^{-1}$ sucrose (complete osmoticum $0.35 \mathrm{M}), 0.5 \mathrm{~g} \cdot$ liter $^{-1}$ malt extract, and $1.2 \%$ purified agar (Sigma). The mixture was plated in five petri dishes $(60 \times 15 \mathrm{~mm}$, Nunc, Roskilde, Denmark). Each petri dish contained about $2 \mathrm{ml}$ final volume of semi-solid medium and $5 \times 10^{5}$ protoplasts.

Protoplast culture and plant regeneration. Protoplasts were cultured in a growth chamber at $27 \mathrm{C}$ with a 16 -h photoperiod at low intensity $\left(100 \mu \cdot \mathrm{mol} \cdot \mathrm{m}^{-2} \cdot \mathrm{s}^{-1}\right)$ as described by Vardi et al. (1982) with some minor modifications. When cell colonies reached $2 \mathrm{~mm}$ in diameter, they were isolated and plated separately for further growth on BM medium (MT $+50 \mathrm{~g} \cdot$ liter $^{-1}$ sucrose $+1 \%$ agar) with $0.5 \mathrm{~g} \cdot \mathrm{liter}^{-1}$ malt extract. Callus colonies were proliferated on the same medium, and well-developed calli were transferred to BM medium supplemented with $20 \mathrm{ml} \cdot$ liter $^{-1}$ glycerol in the place of sucrose to stimulate embryogenesis. The induced embryoids and those spontaneously formed from protoplasts were further cultured on BM containing $1.5 \mathrm{~g} \cdot$ liter $^{-1}$ malt extract. After 1 to 2 months of culture, large, well-shaped embryos were transferred to germination medium $(\mathrm{G}+2)$ composed of $\mathrm{BM}$ containing 2 $\mathrm{mg} \cdot$ liter $^{-1}$ gibberellic acid $\left(\mathrm{GA}_{3}\right)$ and $0.05 \mathrm{mg} \cdot \operatorname{liter}^{-1} \alpha-$ naphthaleneacetic acid (NAA). Resulting shoots were dissected and rooted on MT medium containing $25 \mathrm{~g} \cdot$ liter $^{-1}$ sucrose and 0.05 $\mathrm{mg} \cdot$ liter $^{-1} \mathrm{NAA}$, or grafted directly on 1-year-old potted sour orange rootstocks. Rooted plants were transferred to Jiffy pots and later to regular pots in greenhouse.

\section{Tolerance evaluation of the protoclones}

Three tests (callus and protoplast assays and chitinase analysis) were performed to evaluate the tolerance of the obtained protoclones based on previous results obtained from the early screening of citrus genotypes for tolerance to mal secco (Gentile et al., 1992b, 1994). Susceptible 'Femminello siracusano' and tolerant 'Monachello' were included in all the tests as controls.

Callus assay. Six colonies of callus (about $5 \mathrm{mg}$ each) of the control cultivars and one of the protoclones were plated in a $3-\mathrm{cm}$ petri dish containing BM medium with $1 \mu \mathrm{M}$ toxin. The control was set up by transferring callus on BM without toxin. For each cell line, five dishes were used for the toxin test and five for the control. The callus growth rate was compared after culture for 4 weeks in the growth chamber.

Protoplast assay. Protoplasts isolated from callus and leaf were used. Leaf protoplasts were isolated according to Grosser and Chandler (1987). Tender leaves of full size were sampled from the protoplast-derived plants and from the grafted plants of the control greenhouse-grown cultivars and sterilized by immersion in $1 \mathrm{~N}$ $\mathrm{HCl}$ for $30 \mathrm{sec}$, followed by $15 \mathrm{~min}$ immersion in $1 \%$ sodium hypochlorite containing 3 drops of Tween 20 . Leaves were feathered with a sharp scalpel and incubated in a mixture containing 3 $\mathrm{ml}$ enzyme solution and $7 \mathrm{ml} \mathrm{BH3}$ medium for $14 \mathrm{~h}$ on a rotary shaker at $50 \mathrm{rpm}$ in the dark at $27 \mathrm{C}$. The subsequent procedures were the same as those for callus protoplast isolation. After adjusting the concentration to $5 \times 10^{5}$ cells $/ \mathrm{ml}, 0.5 \mathrm{ml}$ protoplast suspension was mixed with $0.5 \mathrm{ml} 2 \mu \mathrm{M}$ toxin to a final concentration of $1 \mu \mathrm{M}$. In the control, the same volume of BH3 medium replaced the toxin. The assay was repeated twice. Protoplasts were incubated for $1 \mathrm{~h}$ in the growing chamber in the dark. At the end of treatment, protoplasts were stained with fluorescein diacetate (Widholm, 1972). Protoplast viability was scored under an inverted microscope and expressed as percentage of control.
Chitinase analysis. For the extraction of extracellular proteins, suspension cultures of the control cultivars and of one protoclone were established. Callus (800 mg) was placed into liquid MT medium $(20 \mathrm{ml})$ in a $100-\mathrm{ml}$ Erlenmeyer flask on a horizontal shaker at $100 \mathrm{rpm}$ in the growth chamber. After 20 days of culture, liquid medium was collected by centrifugation $(1000 \times \mathrm{g}, 5 \mathrm{~min})$ and filtration $(0.45 \mathrm{pm})$. Proteins were precipitated from the obtained liquid by ethanol at 4C (de Vries et al., 1988). After a centrifugation at $10,000 \times \mathrm{g}$ at $4 \mathrm{C}$ for $30 \mathrm{~min}$, the pellet was resuspended in water.

The intracellular proteins were extracted from mature leaves of the control cultivars and of one somaclone according to the procedure described by Dahan and Sagee (1992). Protein content was measured according to Bradford (1976) and fractionated by denatured sodium dodecyl sulfate-polyacrylamide gel electrophoresis (SDS-PAGE) containing 10\% acrylamide (Laemmli, 1970). Immunoblots were prepared according to Gentile et al. (1993) using the antichitinase specific for lemon and autoradiographed.

\section{Results}

Protoclone isolation and plant regeneration. The 'Femminello siracusano' protoplasts treated with toxin and plated in five petri dishes formed only two colonies after 40 days, while in the control plates the plating efficiency was about $8 \%$. The two colonies from the toxin treatment were isolated and individually transferred to $\mathrm{BM}$ for further growth. One month later, one colony formed embryos, while the other produced callus; they were named 'Siracusano-S 1' and 'Siracusano-S 2', respectively.

The embryos of 'Siracusano-S 1' were transferred to G+2 medium for germination. The well-developed shoots were rooted or grafted directly on sour orange rootstocks. Up to now, six rooted and two grafted plants have been regenerated and they are growing in the greenhouse. Two of these regenerated plants have also been grafted onto mature sour orange trees in the field.

After a period of proliferation, the callus of 'Siracusano-S 2' was transferred to MT medium supplemented with $20 \%$ glycerol to induce embryogenesis. Some embryos were obtained and one plant was recovered.

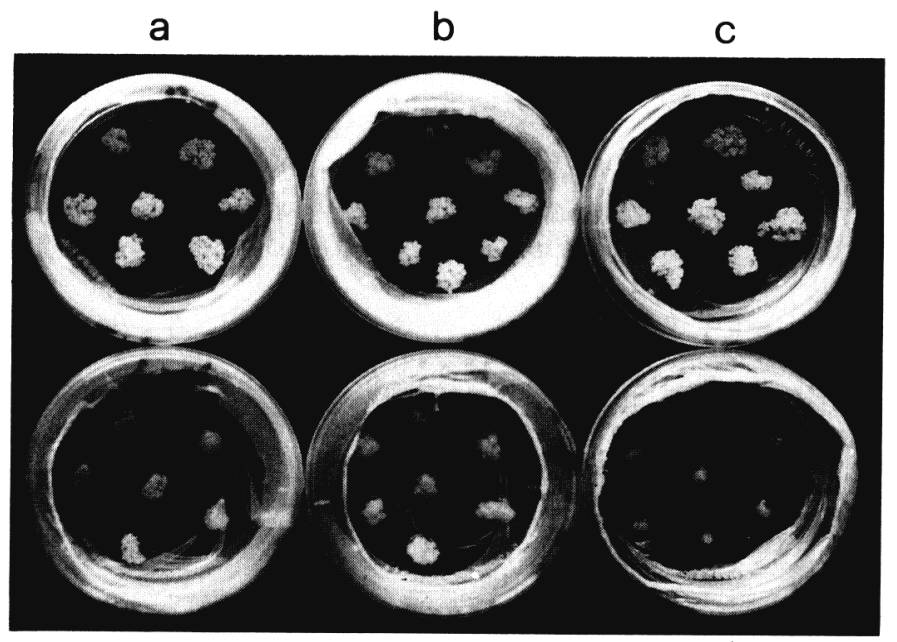

Fig. 1. Callus growth of 'Monachello' (a), 'Siracusano-S 2' (b) and 'Femminello siracusano' (c). Calli were cultured for 28 days on MT medium containing $1 \mu \mathrm{M}$ Phoma tracheiphilu toxin (petri dishes at the bottom) and on MT without toxin (petri dishes on top). 
Table 1. Viability of callus and leaf protoplasts isolated from lemon control cultivars and the protoclones after incubation with $1 \mu \mathrm{M}$ toxin for $1 \mathrm{~h}$. Values are expressed as percentage of the control $(=100 \%)$.

\begin{tabular}{lcc}
\hline \hline Cultivar and protoclone & Leaf protoplasts & Callus protoplasts \\
\hline Monachello & $98.0 \mathrm{~b}^{\mathrm{z}}$ & $97.0 \mathrm{~b}$ \\
Siracusano-S 1 & $97.5 \mathrm{~b}$ & $\mathrm{NA}^{\mathrm{y}}$ \\
Siracusano-S 2 & $95.0 \mathrm{~b}$ & $89.0 \mathrm{~b}$ \\
Femminello siracusano & $69.5 \mathrm{a}$ & $65.5 \mathrm{a}$ \\
\hline
\end{tabular}

${ }^{2}$ In each column values followed by the same letter do not differ significantly by Student's $t$ test $(\mathrm{P}=0.01)$.

'NA = not analyzed.

Callus assay. Because 'Siracusano-S 1' did not produce callus, this assay was performed only with 'Siracusano-S 2'. After 28 days incubation with $1 \mu \mathrm{M}$ toxin, callus of 'Siracusano-S 2' and of tolerant 'Monachello' grew well, similar to those growing on medium without toxin. In contrast, callus growth of susceptible 'Femminello siracusano' was completely inhibited (Fig. 1).

Protoplast assay. The viability of the protoplasts isolated from callus and leaves of the tested genotypes and treated with toxin is shown in Table 1. Quite different responses were detected $1 \mathrm{~h}$ after toxin treatment between the tolerant and the susceptible genotypes. The viability of protoplasts of 'Monachello' and of the two protoclones was about $90 \%$, statistically higher than the $65 \%$ viability of 'Femminello siracusano' protoplasts.

Chitinase analysis. Extracellular proteins extracted from 'Siracusano-S 2', intracellular ones from 'Siracusano-S 1', and extra- and intracellular from 'Monachello' and 'Femminello siracusano' lemons were analyzed using the antichitinase specific for lemon. The extracellular proteins of 'Femminello-S', a somaclone tolerant to the toxin, were also included in the present analysis as a positive control. The immunoblot results indicated that the proteins of the tolerant genotypes have shown high crossreactivity with the antibody, while those extracted from suspension culture and leaves of 'Femminello siracusano' did not show any reaction with the antibody. Two bands were observed, one having an apparent molecular weight of $34 \mathrm{kDa}$ for extracellular and another of $45 \mathrm{kDa}$ for intracellular proteins (Fig. 2). The proteins extracted from 'Siracusano-S 1' leaves presented the 45 and the $34-\mathrm{kDa}$ band. These results clearly indicate that the two protoclones were able to produce chitinase, either in vitro or in vivo, as the mal secco tolerant 'Monachello' lemon.

\section{Discussion}

In the present work, the toxin treatment caused severe plasmolysis and complete inhibition of cell division in 'Femminello siracusano' protoplasts. From about $2 \times 10^{6}$ cells, only two proto-

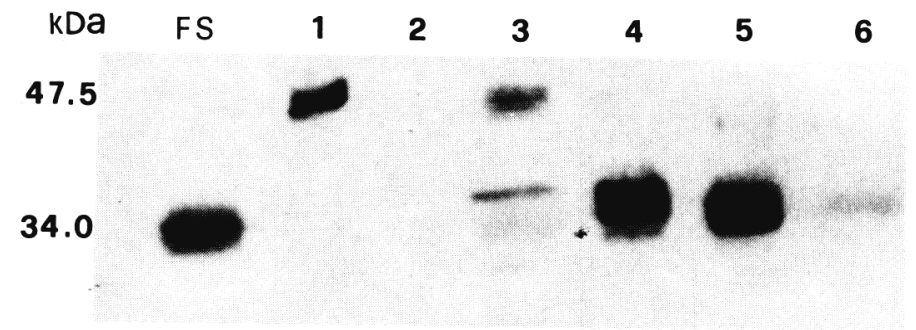

Fig. 2. Western blot analysis of intracellular (lanes 1.2, and 3) and extracellular (FS and lanes 4,5 , and 6) proteins using antichitinase of lemon. FS = 'FemminelloS'; 1 and 5 = 'Monachello'; 2 and 6= 'Femminello siracusano'; $3=$ 'SiracusanoS 1'; and 4 = 'Siracusano-S 2'. plasts survived and formed colonies. Previously, using Phoma tracheiphila toxin, a tolerant line was selected from the embryogenic callus of 'Femminello Continella' lemon (Gentile et al., 1992b). These results suggest that exposing callus and protoplasts to selection pressure created by the toxin is an effective tool for recovering lemon somaclones that show putative tolerance to the disease. Thus, this selection system may also be effective for other ma1 secco-susceptible citrus species, such as sour orange (C. aurantium L.).

Protoplasts were more sensitive to the toxin than calli. In fact, it was observed that the ideal toxin concentration for selection was $1 \mu \mathrm{M}$ for calli, while $0.5 \mu \mathrm{M}$ was effective for protoplasts. In the assay for tolerance, however, 65\% of the 'Femminello siracusano' protoplasts survived the $1 \mu \mathrm{M}$ toxin treatment. The apparent different sensitivities shown in the selection and in the assay were caused by treatment procedures and evaluation parameters applied. In the assay, protoplast viability was evaluated only $1 \mathrm{~h}$ after toxin treatment. At this stage different responses between tolerant and susceptible citrus genotypes were readily detected, but cells that appeared viable by the fluorescence assay may have been damaged. In the selection, immediately after plating, some of the treated protoplasts were broken down, while the others (probably those shown to be viable by fluorescence) remained complete; however, these protoplasts soon were plasmolyzed and never divided. Therefore, very low colony formation was observed 40 days after plating.

An in vitro selection system with single cells (protoplasts) has some advantages over callus. A colony of callus contains a mixture of cells, so it is possible that tolerant cells and some escaped susceptible ones may grow when the selective agent is removed. In our previous selection with 'Femminello Continella' callus, the plants regenerated from the selected callus line segregated from very susceptible to very tolerant to mal secco (Gentile et al., 1992b). In the case of protoplasts, a somaclone is always derived from a single cell, so the plants regenerated from such a protoclone should be uniformly resistant to the selective agent and there should be no escapes. In fact, in our study, the eight plants regenerated from 'Siracusano-S 1' showed very similar tolerance to the toxin in the protoplast assay.

In citrus, chitinase was found in two isoforms. One (34 kDa) was detected in the extracellular proteins extracted from suspension culture and another $(45 \mathrm{kDa})$ in the intracellular proteins from leaves. These two proteins were considered to be products of two different genes (Gentile et al., 1994). In the present assay, both forms of chitinase were detected among the proteins extracted from leaves of one protoclone, 'Siracusano-S 1'. It is not clear whether this phenomenon is related to tolerance to mal secco or not.

In our experiments, the tolerance of two selected protoclones was identical to that of tolerant 'Monachello'. Because they were derived from a commercial cultivar, these protoclones have the potential to be used directly as mal secco-tolerant lemon cultivars after passing juvenility and comprehensive field evaluation. Some plants of 'Siracusano-S 1' have already been grafted on mature sour orange stocks in a lemon experimental block. The same field comparison will be established at the earliest possibility with 'Siracusano-S 2'.

\section{Literature Cited}

Bradford, M.M. 1976. A rapid and sensitive method for the quantification of micrograms quantities of protein utilizing the principle of protein-dye binding. Anal. Biochem. 72:248-254.

Dahan, Y. and O. Sagee. 1992. Effects of ethylene on the induction of $\beta-$ 
1,3-glucanase and chitinase in citrus leaves. Proc. Intl. Soc. Citricult. 1:383-386.

Daub, M.E. 1986. Tissue culture and the selection of resistance to pathogens. Annu. Rev. Phytopathol. 24:159-186.

Deng, Z.N., A. Gentile, F. Domina, E. Nicolosi, E. Tribulato, and A. Vardi. 1995. Recovery of citrus somatic hybrids tolerant to Phoma trucheiphilu toxin, combining selection and identification by RAPD markers, p. 177-183. In: M. Terzi, R. Cella, and A. Falavigna (eds.). Current issues in plant molecular and cellular biology. Kluwer Acad. Publ., Dordrecht, The Netherlands.

de Vries, S.C., H. Booij, R. Jaussens, R. Vogels, L. Saris, F. Lo Schiavo, M. Terzi, and A. Van Kammen. 1988. Carrot somatic embryogenesis depends on the phytohormon-controlled presence of correctly glycosylated extracellular proteins. Genes Dev. 2:462-476.

Gentile, A. and Z.N. Deng. 1992. Effects of growth regulators on induction and early maintenance of lemon embryogenic callus. Proc. Intl. Soc. Citricult. 1:163-165.

Gentile, A., E. Tribulato, G. Continella, and A. Vardi. 1992a. Differential responses of citrus calli and protoplasts to culture filtrate and toxin of Phoma tracheiphila. Theor. Appl. Genet. 83:759-764.

Gentile, A., E. Tribulato, Z.N. Deng, and A. Vardi. 1992b. In vitro selection of nucellar lemon callus and regeneration of plants tolerant to Phoma tracheiphila toxin. Adv. Hort. Sci. 4:151-154.

Gentile, A., E. Tribulato, Z.N. Deng, E. Gahm, R. Fluhr, and A. Vardi. 1993. Nucellar callus of 'Femminello' lemon, selected for tolerance to Phoma tracheiphila toxin, shows enhanced release of chitinase and glucanase into the culture medium. Theor. Appl. Genet. 86:527-532.

Gentile, A., E. Tribulato, Z.N. Deng, F. Domina, F. Galun, R. Fluhr, and A. Vardi. 1994. Rilascio di proteine PR, in vitro ed in vivo, in diversi genotipi di agrumi con noto comportamento nei confronti del mal secco. Italus Hortus 1(3):59-64.

Grosser, J.W. and J.L. Chandler. 1987. Aseptic isolation of leaf protoplasts from Citrus, Poncirus, Poncirus x Citrus hybrids and Severinia for use in somatic hybridization experiments. Scientia Hort. 31:253257.

Grosser, J.W. and F. Gmitter, Jr. 1990. Protoplast fusion and citrus improvement. Plant Breed. Rev. 8:339-374.

Hammerschlag, F.A. 1992. Somaclonal variation, p. 35-55. In: F.A. Hammerschlag and R.E. Litz (eds.). Biotechnology of perennial fruit crops. CAB Intl., Wallingford, U.K.

Laemmli, U.K. 1970. Cleavage of structural proteins during the assembly of the head of bacteriophage T4. Nature 227:680-685.

Linthorst, H.J.M. 1991. Pathogenesis-related proteins of plants. Crit. Rev. Plant Sci. 10:123-150.

Murashige, T. and D.P.H. Tucker. 1969. Growth factors requirements of citrus tissue culture. Proc. 1st Intl. Citrus Symp. 3:1155-1161.

Nachmias, A., I. Barash, Z. Solel, and G.A. Strobel. 1977. Purification and characterization of a phytotoxin produced by Phoma tracheiphila, the causal agent of mal secco disease of citrus. Physiol. Plant Pathol. 10:147-157.

Pennisi, A.M., G. Di Pasquale, M. Bonforte, and F. Sesto. 1988. Phytotoxic metabolites of ipo-virulent and virulent Phoma tracheiphila isolates. Proc. Intl. Soc. Citricult. 2:817-826.

Russo, F. and E. Tribulato. 1986. La ricerca e il miglioramento genetico degli agrumi. Il Recente Contributo della Ricerca allo Sviluppo dell'Agrumicoltura Italiana, Cagliari, Italia. p. 23-29.

Tusa, N., J.W. Grosser, and F.G. Gmitter, Jr. 1990. Plant regeneration of 'Valencia' sweet orange, 'Femminello' lemon, and the interspecific somatic hybrid following protoplast fusion. J. Amer. Soc. Hort. Sci. 115:1043-1046.

Vardi, A., P. Spiegel-Roy, and E. Galun. 1982. Plant regeneration from Citrus protoplasts: Variability in methodological requirements among cultivars and species. Theor. Appl. Genet. 62:171-176.

Widholm, J.M. 1972. The use of fluorescein diacetate and phenosafranine for determining viability of cultured plant cells. Stain Technol. 47:189194. 